\title{
脳外科用レーザーパルスジェットメスハンドピースの使用感向上 設計と評価に関する研究 \\ Design and validation for improve usability of Laser Induced Liquid Jet hand piece
}

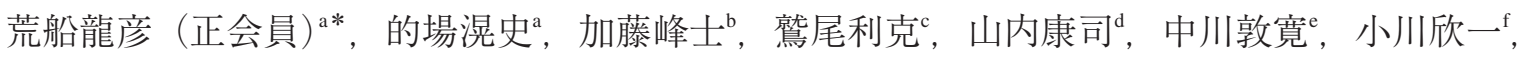 \\ 冨永悌二，舟久保昭夫 ${ }^{\mathrm{a}}$ \\ a 東京電機大学理工学部 \\ $\mathrm{b}$ 東京大学大学院工学系研究科 \\ c 産業技術総合研究所 \\ $\mathrm{d}$ 東洋大学理工学部 \\ $\mathrm{e}$ 東北大学大学院医学系研究科医科学専攻神経外科学分野 \\ $\mathrm{f}$ 広南病院脳神経外科
}

Tatsuhiko Arafune ${ }^{a}$, Hiroshi Matoba ${ }^{a}$, Takashi Kato ${ }^{b}$, Toshikatsu Washio ${ }^{c}$,

Yasushi Yamauchi ${ }^{\mathrm{d}}$, Atsuhiro Nakagawa ${ }^{\mathrm{e}}$, Yoshikazu Ogawa ${ }^{\mathrm{f}}$, Teiji Tominaga ${ }^{\mathrm{g}}$, Akio Funakubo ${ }^{\mathrm{a}}$

${ }^{a}$ School of Science and Engineering, Tokyo Denki University

${ }^{\mathrm{b}}$ Graduate School of Engineering, The University of Tokyo

${ }^{c}$ National Institute of Advanced Industrial Science and Technology

${ }^{\mathrm{d}}$ Faculty of Science and Engineering, Toyo University

${ }^{\text {e }}$ Department of Neurosurgery, Tohoku University Graduate School of Medicine

${ }^{\mathrm{f}}$ Department of Neurosurgery, Kohnan Hospital

\begin{abstract}
As a new surgical device to accomplish both maximum tumor removal and functional preservation, Laser Induced Liquid Jet (LILJ) has been developed. Since 2011, the multicenter clinical trial has commenced intended pituitary tumor removal in 7 hospitals, all of whom were assigned to high volume center of pituitary tumor treatment in Japan, and they encountered over 100 cases in total. From the questionnaire filled by the surgeons, the surgeons desired the usability of LILJ hand piece to be improved. In this study, we designed and attached a new grip adapter for hand piece, and evaluated it in terms of weight center control, moment, and robustness against disturbance input in ergonomic experiments. In the results, the hand piece with the new grip adapter accomplished the reduction of the applied force by each finger from 1.4 to $0.4 \mathrm{mN}(29 \%)$ and the error distance by mistaken fire from 19.5 to $9.1 \mathrm{~mm}$ (47\%). Hence, the stability and operability of the LILJ hand piece were progressed.
\end{abstract}

Key word

medical water jet, handheld device usability, transsphenoidal surgery, ergonomic evaluation

*東京電機大学理工学部
干 $350-0394$ 埼玉県比企郡鳩山町石坂
arafune.t@ mail.dendai.ac.jp
受付 2014 年 8 月 22 日 ; 採択 2015 年 2 月 4 日

\section{1. 研究背景}

1.1 レーザーパルスジェットメス概要 外科手術では救命率や腫瘍摘出率の向上のみなら ず, 低侵襲と機能の最大限温存することの両立が求 


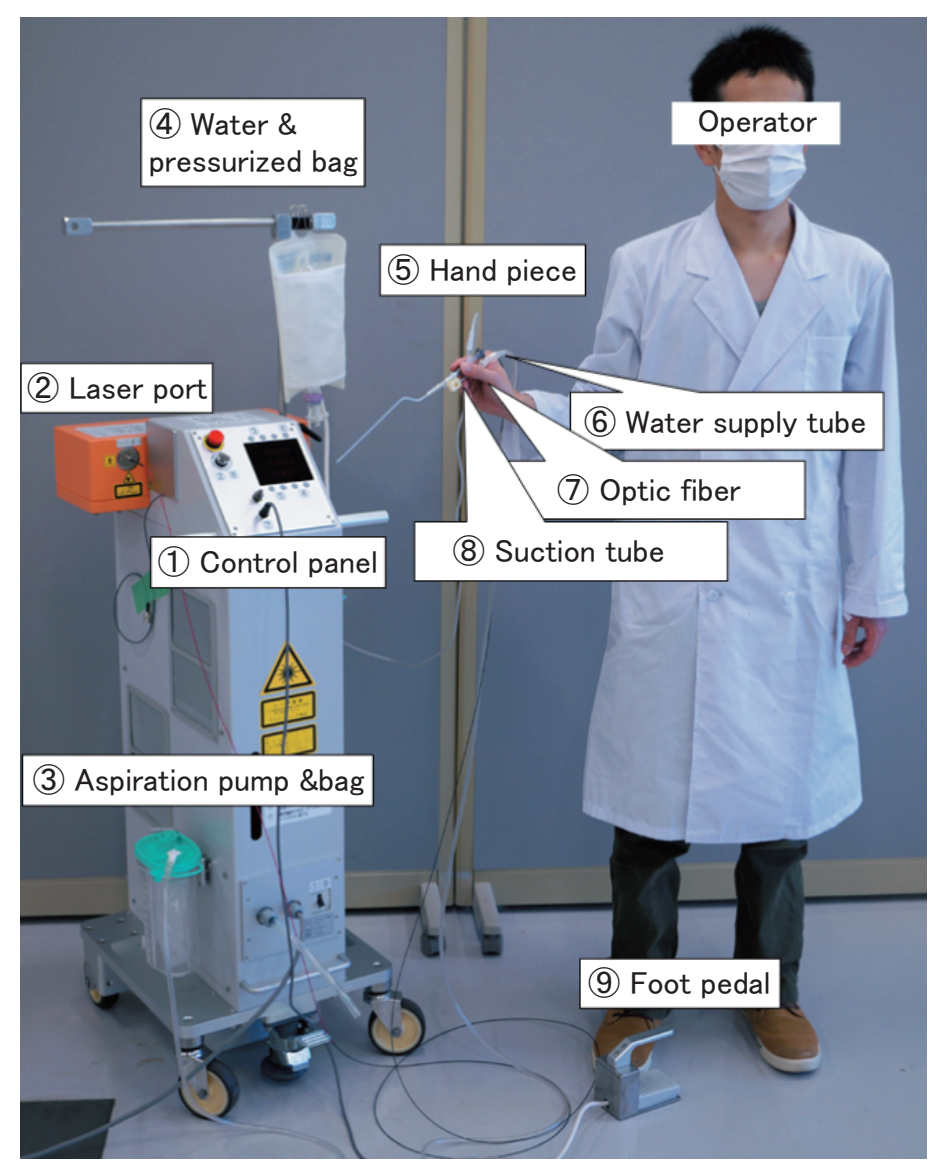

Fig.1 LILJ system configurations.

められる時代である。一方で医療技術の高度化と, 標 準化への要求がますます高まっており, 医療機器も これらの時代要請に応えるものでなくてはならない． そこで我々は脳外科手術を対象として, “腫瘍摘出” と“神経・血管の温存”の両立を目指し, 従来に無い 新しい発想の治療機器であるレーザーパルスジェッ トメスの開発を行ってきた ${ }^{1-4)}$.

レーザーパルスジェットメス (laser induced pulsed liquid jet：以下, LILJ) は, Ho. YAG レーザーを動力 源とし, 微量の液体を高速かつ間欠式に射出し, この 液体ジェットと腫瘍組織の衝突による物理作用に よって腫瘍破砕を行う治療機器である. Fig. 1 に LILJ の装置概要を示す.

LILJ 図中(1)から(9)がそれぞれ以下の要素で構成さ れる。

(1)レーザー出力や周波数を設定する制御パネル

(2)光ファイバを接続するレーザー駆動ユニット

(3)破砕した組織や血液を吸引し溜める吸引バッグ

(4)液体ジェットの供給元となる輸液と加圧バッグ
(5)術者が操作するハンドピース

(6)ハンドピースに給水する輸液チューブ

(7)ハンドピースに接続する光ファイバ

(8)ハンドピースから吸引する吸引チューブ

(9)ジェット出力を決定するフットペダル

Fig. 1, (5)ハンドピースは, 金属細管等から構成 されるハンドピース部分と，ハンドピースに接続さ れる3つのケーブル類（Fig. 1，6輸液チューブ， (7) 光ファイバ, 8吸引チューブ）から構成される.

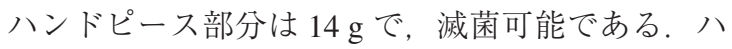
ンドピース後部に Y 字コネクタを取り付け, Y 字コ ネクタのストレートな挿入口から光ファイバを，も う一方の口に輸液チューブを接続する。 ハンドピー スの構成図を Fig. 2 に示す。

ハンドピースはジェット射出と吸引管の両方の役 割を兼ねている. Fig. 3 にハンドピース内部構造を示 す。ステンレス細管の外側にはテフロンチューブが 被覆され, ステンレス細管とテフロンチューブの隙 間から液体と破砕した組織を吸引可能である。その 


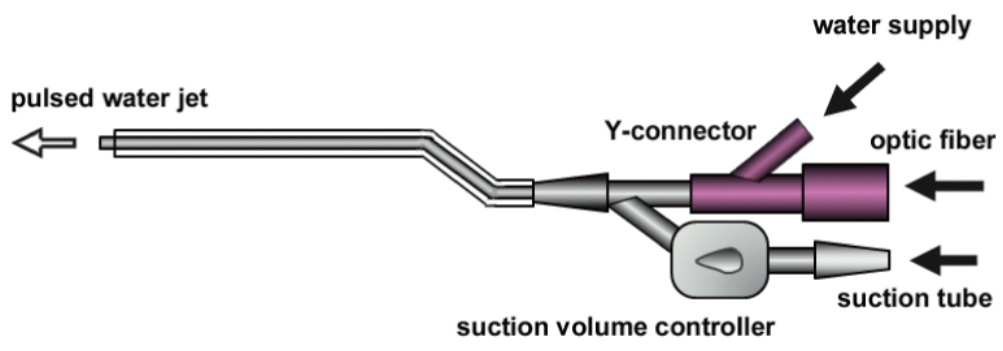

Fig.2 LILJ hand applicator were configured stainless fine tube and suction volume controller and $\mathrm{Y}$-connector. Water supply tube, suction tube and optic fiber were set on the back of hand piece.
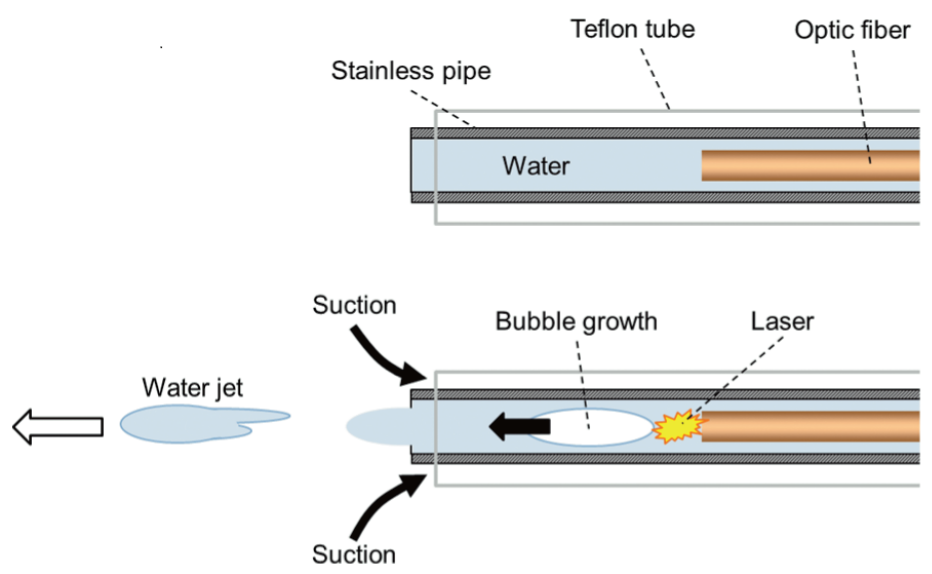

Fig.3 High speed pulsed water jet were driven by vapor bubble growth provoked by $\mathrm{Ho}^{-}$YAG pulsed laser.

ためハンドピース後部に吸引チューブが取り付けら れるようになっており，吸引チューブは LILJ 本体の 吸引ポンプへ接続される。吸引チューブは全長 $2 \mathrm{~m}$ で重量が約 $110 \mathrm{~g}$ である。 ハンドピースの吸引チュー ブに繋がる接続部には涙型の切欠きの入った吸引制 御ブロックが取り付けてあり，通常はこの部分が開 放端となって吸引されないが, この部分を指で塞ぐ ことで金属細管とテフロンチューブの隙間に陰圧が 生じて吸引が可能となる。この切欠きに指を置き, 指 の位置を緻密にずらすことで吸引圧の制御が可能で ある。

内径 $1 \mathrm{~mm}$ のステンレス細管の中に送水された液 体を満たし, 径 $0.6 \mathrm{~mm}$ の光ファイバを細管の半ば まで導管する，光ファイバはジェットメス装置本体 のレーザー出力ポートに接続されており, ファイバ を通じて $300 \mu \mathrm{s}$ のパルス幅のパルスレーザーが印加 される。レーザーが印加されると細管内のレーザー 端面に接している液体が瞬間的に沸騰して気化し， その気体膨脹の作用を利用して, 細管先端から液体
が高速に射出される

レーザー駆動装置の出力設定が $0.7 \mathrm{kV}$ の場合, 射 出される液体ジェット 1 発は約 $10 \mu \mathrm{l}$, 速度は約 20 $\mathrm{m} / \mathrm{s}$ となる.

LILJ の操作方法としては以下の手順で行う.

1 ）装置本体の電源スイッチを入れて起動後, 操 作パネルでレーザー発振の周波数, 出力を設 定

2) 輸液バッグに取り付けられた加圧バッグ（Fig. 1 (4)）を適度に加圧してハンドピース先端から 輸液がおよそ一秒に一滴ほどの少量が継続的 に出るように調整する

3 ）装置本体の操作パネルのレーザー出力安全装 置を解除

4）フットペダル（Fig. 1 9)）を踏むことで，ハン ドピース先端より液体ジェットが設定した周 波数 $(1 \sim 10 \mathrm{~Hz})$ で繰り返し射出される. 


\subsection{LILJ を用いた臨床研究結果}

LILJ 装置を用いた前臨床研究を経て，2001 年には ヒト下垂体腫瘍線種摘出術を対象とした臨床研究を 実施した ${ }^{5)}$. 腫瘍破砕と血管神経の温存の両立を目的 とした治療機器としては, 超音波吸引器や外科用連 続流ウォータージェットメスが他に知られている が()，LILJ は従来機器でも困難だった, 脳外科下垂体 腫瘍線種摘出術における腫瘍組織の破砕と, 径 0.2 $\mathrm{mm}$ の細動脈血管温存を両立しながら，手術時間，出 血量，予後，いずれも優れた治療成績を実現し，既報 にて報告した ${ }^{1)-4)}$.

さらに，2012 年 3 月より LILJを用いた国内 7 施設 (東北大学病院, 広南病院, 東京女子医科大学病院, 東京女子医科大学八千代病院，千葉大学病院，日本医 科大学病院, 熊本大学病院 (順不同)）における多施 設臨床研究を実施し，合計 100 症例以上の下垂体腫 瘍摘出手術とそれと同時に術者に対する全例アン ケートを実施した。

前期，後期に分割したアンケート収集の前期 52 件 に扔けるジェットメスハンドピースに関する設問『ハ ンドピースの持ちやすさ』（持ちやすい，持ちにくい， の選択回答）において，21\%が持ちにくいと回答が あった。またアンケート自由記入回答欄において術 者より要望として指摘された事項のうち, 主要なも のの 1 つがハンドピースに関するもので，接続され た各種ケーブル類の取り回しによる操作感の低下や, 持ちにくいデザインに関して改善要望の指摘があっ た，LILJ ハンドピースを構成する，吸引管や給水管， 光ファイバなどの様々なケーブル類がハンドピース 後部に接続されており, 術者からはハンドピースが 軽量すぎるとの指摘や，吸引チューブの屈曲硬さか ら生じるモーメントが微細な操作の妨げとなること が指摘された。 LILJ 使用時においてチューブやファ イバの脱落およびそれによる誤操作，過剩切除等の 重大な瑕疵は認められなかったが，一方でインシデ ントとまでは呼ばないまでも通常使用において術者 が不快感を抱く事があると考えられた。

以上の課題から，本研究は，LILJ ハンドピース使 用時の不安定性や意図を妨げる要因からくる不快感 を低減し，より安定した使用感を感じることのでき るハンドピースの設計㧍よびその評価を行うことを 目的とする

\section{2. 研究方法}

2.1 多施設臨床研究からの使用感に関する課題 抽出

多施設臨床研究で実施したアンケートにはハンド ピース使用感に関する細かな設問は無かったため, 医療従事者側のニーズ，改善すべき点が明確ではな い.そこで臨床研究で撮影された下垂体治療におけ るLILJ 使用中のビデオ映像や，機器取扱いプロトコ ルを改めて見直し，ハンドピース設計における具体 的なパラメータの抽出とそれを元にした要求仕様を 決定した。

\subsection{1 アンケート内容と結果}

2012 年に実施した多施設臨床研究における術者ア ンケート項目は主に医学的な観点から設問が設定さ れており，16の大問は以下となる.

Q1 通し番号

Q2 年齢

Q3 性別

Q4 手術日

Q5 診断（疾患名，組織型，大きさ，等)

Q6 手術情報 (手術時間, 出血量, 術後 MRI 診断等)

Q7 ジェット使用による，意図しないくも膜の損傷 の有無

Q8 ジェット使用による, 意図しない海面静脈洞内 側壁損傷の有無

Q9 動脈温存（温存できた血管長等）

Q10 静脈温存（温存できた血管長等）

Q11 術後出血（術後 CT 評価による不測の後出血の 有無)

Q12 末梢神経温存（できた神経，機能評価，検査の 種類等)

Q13 他の腫瘍破砕装置との比較（併用ありなし等）

Q14 使い勝手について

Q15 手術前後の下垂体機能について（術後の分泌能 低下ありなし，低下していたもの等)

Q16 使用中特に気がついたことについて自由記入

このうちハンドピースの操作性に関する設問は

Q14であり, Q14 の小設問は以下である.

1 ) 今回の使用出力とパルス周波数（值入力）

2 ) 現状の破砕・切開能力の調整幅で (十分, 不十 分の二択)

3 ) ハンドピースの持ちやすさは現状で（持ちや すい, 持ちにくいの二択) 


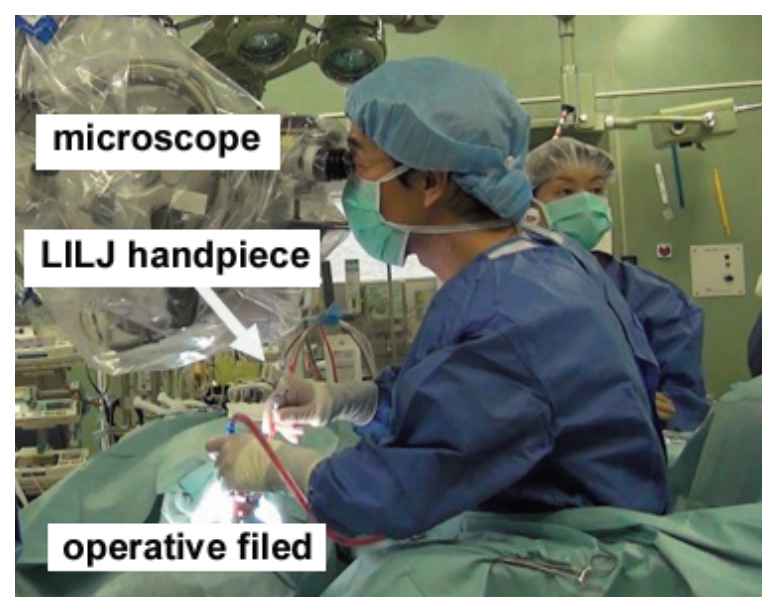

Fig.4 Operator posture using LILJ in transsphenoidal surgery

4 ）機械出し・外回りへの方への質問. 現在のシス テムは（使いやすい，使いにくいの二択）

5 ）自由記入

その結果, Q14 小問の回答は下記となった。

2 ）十分 33 , 不十分 12 , 記載なし 7

3 ) 持ちやすい 41 , 持ちにくい 11

4）使いやすい 13 , 使いにくい 38

以上の結果から, LILJ の出力や破砕力などの性能 に関するニーズょりも, 使い勝手の向上へのニーズ が強い事が明らかとなった。

\subsection{2 脳外科下垂体手術における LILJ の使用状 況}

多施設臨床研究を実施した一医療施設に扔いて手 術時に撮影したビデオ映像から，LILJを用いた下垂 体腫瘍線種切除手術工程の観察を行い, 次の事が明 らかとなった。

・経蝶骨洞手術時には患者の鼻の下から上歯の間 を約 20〜30 mm 切開して術野を形成する。 その内部 にジェットメスと血管吻合装置, あるいはジェット メスと別の吸引管 (吸引用途の他, 術野確保用途を含 む）を同時に挿入することもあり，実際のワーキング スペースは 20〜30 mm 径の円筒状空間となる

・腫瘍切除の間は, 術者はクーパー, 高周波血管吻 合装置, LILJ ハンドピースを頻繁に持ち替えながら 手術を行う。その際の 1 つの機器の連続使用時間は 20〜60 秒間程度であった。

・機器の取り換えが頻繁なため, 効率的な機器出 しの面からハンドピースの吸引管チューブを術者の
手近な手術台やハンガー等に固定しておくことが難 しい. 少し離れた位置に置かれた LILJ 装置本体と接 続された吸引管チューブの固定端からの距離が長く なることが, 結果的に操作時の軽妙な動きを妨げて いる.

・LILJ ハンドピース使用時は顕微鏡を介しながら の観察のため, 術者の姿勢は Fig. 4 に示すように, 座った状態で, 術野とハンドピース位置は下方だが, 顔は前を向いているという姿勢を取る。

・『LILJ ハンドピースの精緻な操作』は具体的に 2 つあり，1つはハンドピース細管の精緻な位置調整, もう 1 つは保持手の親指の位置調整による吸引管圧 調整操作である. 両方とも最大数 $\mathrm{mm}$ の位置変化を 制御しており, 術者は $\mathrm{mm}$ 単位での差を認識しなが ら操作している。つまり本研究で行うハンドピース の改良によって, どちらか一方でも操作の空間解像 度が低い方へ大きく変化した場合, 全体の統合され た操作に悪影響が出る可能性がある.

・ ハンドピースの保持には, 親指, 人差し指, 中指 の 3 本が用いられ, 薬指と小指は曲げられて保持に は用いられない。さらに親指は吸引圧調整の役割を 兼ねるため, 操作上実質的に指 2 本しか保持に用い られないタイミングが生じる。

・时はほぼ 90 度に曲げているが肘掛け等に肘はつ かない.

以上の観察結果から, 本研究では LILJ の駆動原理 や設計は大きく変えずに, 新しい保持の仕方を提案 することとする. 具体的には, 現在保持に用いていな い薬指と小指に保持の役割を持たせ, 吸引圧調整に 用いる親指を保持の役割から開放し，保持に用いな くても安定した保持が可能になるようにする.

そこで以上の課題を実現するため, 従来のハンド ピースに，保持のためのグリップアダプタを装着す る方法を選択した。

\subsection{3 グリップアダプタの要求仕様}

以上より,グリップアダプタを装着したハンドピー スの設計指針として以下の要件を満たすものとする。

1) 適切な重量にする

2 ) LILJ の基本構成を維持し, 吸引ボタンへの指 の置き方は変えない

3 ) 術者が保持する手との接着領域を十分に確保 する

4) 保持時にハンドピース全体にかかる力のベク 


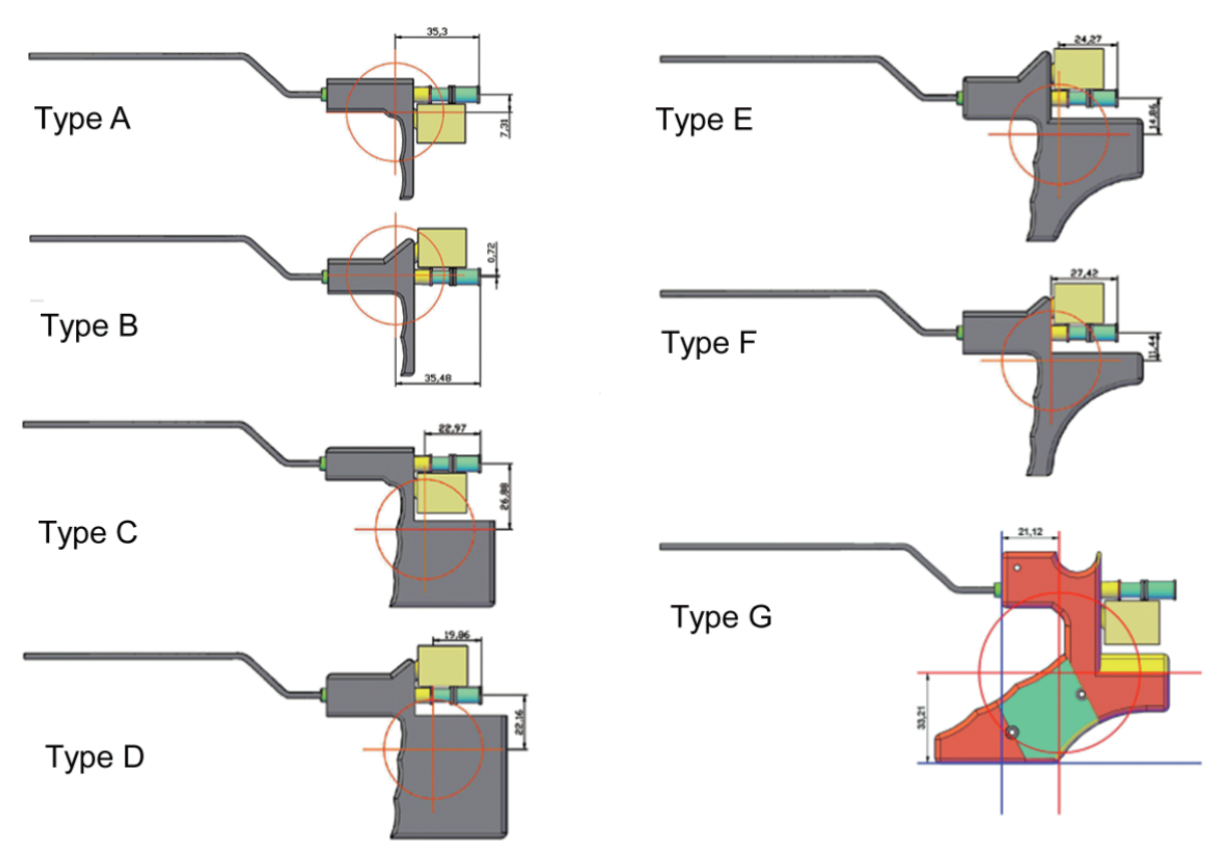

Fig.5 Type A to G are grip adapter CAD design. Red circle and cross shape means center of gravity

\section{トルが偏らないようにする}

5 ) 全体の重心が術者の手の中心に位置する

また，本研究においてジェットメスハンドピース の操作性を『ハンドピース操作を物理的に妨げるよ うな外乱が印加された環境で, 使用意図を逸脱せず に使用し続けられるジェット射出範囲』と定義し, こ れを開発したグリップアダプタの有り/無し両方で計 測し比較することで, グリップアダプタの評価指標 と定めた，その評価の際，以下の要件を勘案するもの とする.

1. 使用姿勢, 手首の角度, が従来のハンドピース と大きく変わらないことで同じ操作勘を継続 する

2、被験者を用いた評価を行う場合, 1 回の被験者 実験のメニューはLILJ 連続使用時間と同様の 約 20 秒以内で終わるメニューとする

\section{2 ハンドピース用グリップアダプタの設計と 製作}

\subsection{1 グリップアダプタの CAD 設計}

グリップアダプタの設計は CAD で行った後，まず 石膏粉末積層型の $3 \mathrm{D}$ 出力機 Zprinter $750^{\mathrm{TM}}$ (Zコーポ レーション社）を用いて出力する. 出力品はそのまま では脆いため, プラスチック樹脂キャストアイボ リー ${ }^{\mathrm{TM}}$ (WAVE 社) へ素材置換し, さらにその後, 実
際に手に持った感触や握り心地に合わせて, 切削等 の加工や表面処理を加えた。

具体的なグリップ設計指針として，まず従来の八 ンドピース保持時には何も保持しておらずフリーな 状態であった薬指, 小指でグリップ部を保持し, 従来 ハンドピース単体のほとんどを支えていた人差し指, 親指の付け根には, 従来通りの感触・ 反力を術者へ返 し, 違和感を低減させるためハンドピースもしくは グリップ部が触れるようにした。グリップ部を作る ことでフリーな状態だった中指にグリップを握る役 割を与えた。設計した一次試作グリップのデザイン を Fig. 5 の Type A〜Gに，またそれぞれのタイプの 特徵を以下に示す.

Type A: 中指, 薬指でグリップ保持する部分を作り, 大きさを最小にしたもの

Type B：Type A から人差し指の保持面積をより大 きくしたもの

Type C : Type A からグリップ部を大きくし中指, 薬指，小指でグリップ保持するようにしたもの

Type D : Type B からグリップ部を大きくし中指, 薬指，小指でグリップ保持するようにしたもの

Type E : Type D から手の親指付け根部分の形状に 沿うよう形状を一部切除したもの

Type F：Type Eより切除領域をより大きくしたも の 


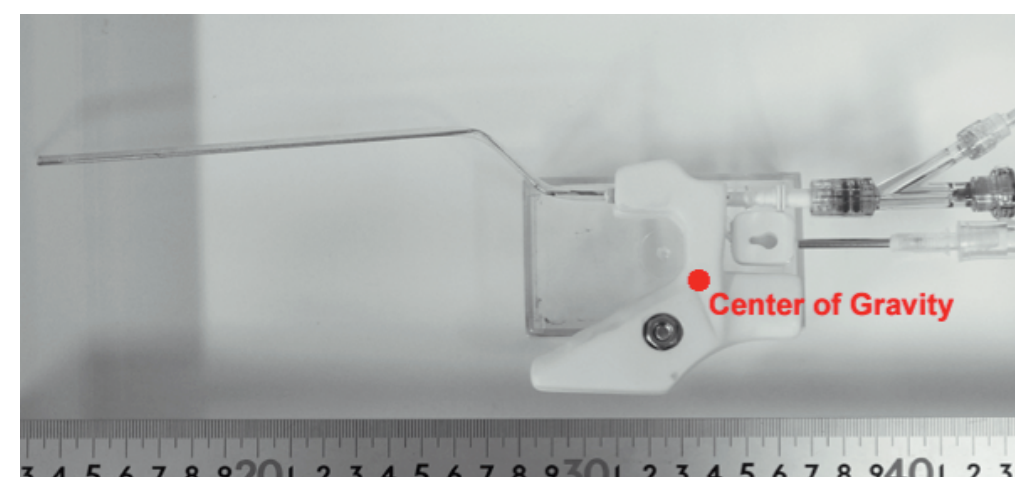

Fig.6 LILJ hand piece with Type G grip adapter. Red circle means a center of gravity

Type G：Type Eよりも薬指, 小指でグリップ保持 する部分をより大きくし，さらに人差し指保持部分 を凹にしたもの.

\subsection{2 グリップアダプタの重心評価}

ハンドピースとグリップアダプタを組み合わせ， $\mathrm{CAD}$ 上で重心位置を計算したものを Fig. 5 中に, 赤 線の丸十字で同時に示した。

グリップアダプタについてはいずれもハンドピー スに取り付けて保持した際に，ちょうど手のひら中 心の位置に重心が来る事を確認した。

\subsection{3 ハンドピース保持時の手首角度評価}

設計したハンドピースを三次元出力および樹脂素 材への置換を行い, 実際にハンドピースに取り付け たものを保持し，操作感を確認した，ハンドピースへ の取り付け方法は, まずグリップアダプタを, アプリ ケータを左右から挟み込むように 2 パーツに分割し，

一方のパーツにM6 ステンレスナットを埋め込み， 2 パーツにM6 ステンレスボルトを加えた 3 パーツ構 成とした。

ハンドピース先端部の術野への挿入角度が術中同 様になるように保持した際, 手首の曲げ角度がグリッ プアダプタ有り/無しでほぼ同じになる事や術者の手 にかかる負担を確認した，その結果 Type G が手首へ の負担や違和感が小さいとの意見が得られ，この時 点で形状を Type G に絞り込み, 以降の評価実験を 行った

樹脂に起こした Type G をハンドピースに取り付け た写真を Fig. 6 に示す.Fig. 6 中の赤丸にハンドピー 久込みの状態での重心位置を示した，CAD データと 大きなずれが無いことを確認した。

\subsection{4 グリップアダプター次試作における保持 手指位置評価}

ハンドピース単体の重心位置および，保持した際 の手の位置をオーバーレイしたものを Fig. 7 (A) に, Type Gのグリップアダプタを装着した時の重心位置 および保持の手の位置を示したものを Fig. 7 （B）に, そして実際に出力したグリップアダプタ付きハンド ピースを術中と同様の角度で保持したものを Fig. 7 （C）に示した. Fig. 7 (A) に示寸通り, ハンドピース 単体を保持した際，ハンドピースの重心が人差し指 第 2 関節付近に位置しており, 物体を安定して保持 できる手のひらの中心に無い，そのため，実際の術中 に安定して使用している場合には重心位置が前方に あるが，術中にケーブルの取り回しや意図せぬケー ブルの大きな位置変化が生じた際には重心がケーブ ル類を接続するハンドピース後方部に移動する可能 性がある，それまで手首前方にあった重心が突然術 者の予想しない後方に変化することで, 操作感の不 快感や不安定性に繋がっていたと考えられる。一方， グリップアダプタを取り付けることで全体的な保持 力が向上すると共に, 重心位置が手のひら中心に位 置することで, 多少の重心位置変化が生じても手首 内にて完結することで, 術者の予想しない操作感に なる状況を低減できることが示唆された。

\subsection{5 吸引管ケーブルによるモーメント評価}

ハンドピースを使用する際，使用者は常に後部に 取り付けた吸引管ケーブルの重量から生じるモーメ ントを制御しながら操作する。そこで Fig. 7 図中 (A) （B）で求めた重心を回転軸と仮定した場合に，吸引 管ケーブルの重量 $(110 \mathrm{~g})$ によって回転軸周りに生 じるモーメントを求めた。模式図を Fig. 8 に示す. 手 

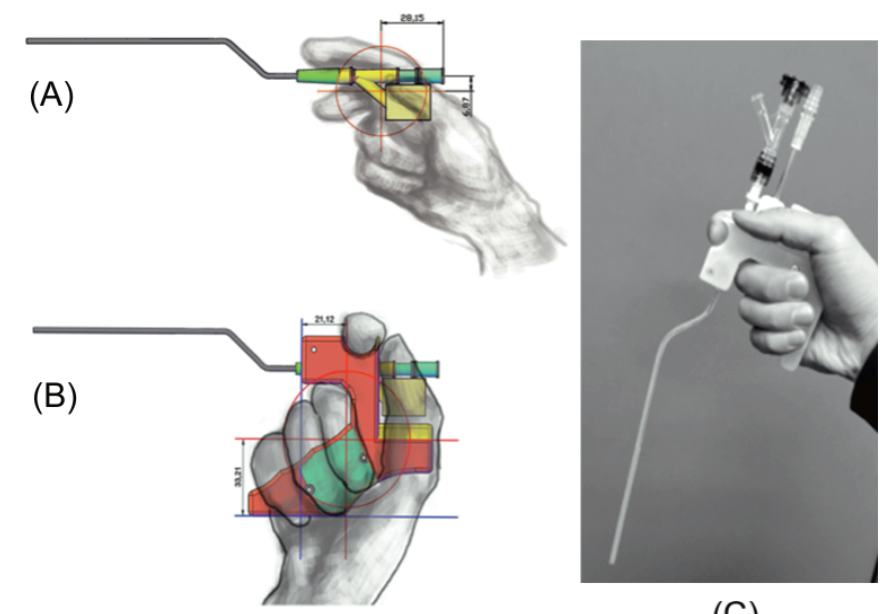

(C)

Fig.7 Holding images of LILJ hand piece.
(A) Original hand piece
(B) Hand piece with Type G grip adapter
(C) Holding hand and hand piece with Type G grip adapter

指とハンドピース拉よびグリップが触れる $\mathrm{A} \sim \mathrm{H}$ の 各作用点に生じる力の作用線を黒の点線で, 吸引管 ケーブル重力の重心からのモーメントアームを赤の 実線で, 各作用点に扔ける重心からのモーメントアー ムを青い実線で示した。

Fig. 8 左図のグリップ無しの場合，ハンドピースと 接しているのは, 人差し指 $(A)$, 中指 $(B)$, 親指 $(C)$ であった。一方，Fig.8 右図のグリップ有の場合，八 ンドピースと接する手抢よび指は, 薬指 $(D)$, 人差し 指 $(E)$, 掌 $(F)$, 薬指 $(G)$, 小指 $(H)$ であった。 八 ンドピースを Fig. 7 (C) のように実際の術中使用の 角度に保持した場合， $\theta_{1}, \theta_{2}$ はそれぞれ $\theta_{1}=30^{\circ}, \theta_{2}=$ $15^{\circ}$ であった。

以上より吸引管の重量によって重心回転軸に生じ るモーメントは重力 $N_{0} \times$ モーメントアーム $r$ の外積 として

$$
\text { グリップ無の場合 }
$$$$
110 \times 10^{-3} \times 9.8 \times \sin 30^{\circ} \times 40 \times 10^{-3}=21.6 \times 10^{-3}
$$

$[\mathrm{Nm}]$

グリップ有の場合

$$
110 \times 10^{-3} \times 9.8 \times \sin 15^{\circ} \times 40 \times 10^{-3}=11.2 \times 10^{-3}
$$

[Nm]

であった。

各作用点に执いて手指からハンドピースに掛かる 力は全て同じと仮定すると, グリップアダプタ無し の場合の各作用点に掛かる力を $N_{l}$, グリップアダプ 夕有の場合の作用点に掛かる力を $N_{2}$ として, 同様に
各作用ベクトルとモーメントアームのなす角度を求 め, 上記で求めた吸引管ケーブルによるモーメント と反対に働くモーメントのみの総和は以下となる. グリップ無の場合 :

$$
N_{l} \times 15.4[\mathrm{Nm}]
$$

グリップ有の場合 :

$$
\mathrm{N}_{2} \times 28.2[\mathrm{Nm}]
$$

このモーメントが吸引管ケーブルによるモーメン トと等しいことから

$$
\begin{aligned}
& N_{1}=1.40 \times 10^{-3}[\mathrm{~N}] \\
& N^{2}=0.4 \times 10^{-3}[\mathrm{~N}]
\end{aligned}
$$

となり，以上よりグリップアダプタを装着すること で，手指がハンドピースに掛ける力を $29 \%$ に低減で きることが示唆された。

\section{3 外乱入力に対する操作ロバスト性評価被験 者実験}

製作し単体での物理的な評価等を行った LILJ ハン ドピースグリップアダプタの操作性を被験者実験に よって評価した。

\subsection{1 評価実験システム}

ジェットを撃つ対象としては, ゼラチンファント ムを用意した。撥水性ビニールコートを施した紙に 12 個の丸印とそれらを一筆描きに繋げた直線から成 る基準パターンを印字し, 重量比 4\%のゼラチンを入 れた容器底面に沈め, 評価実験用ファントムとした。 


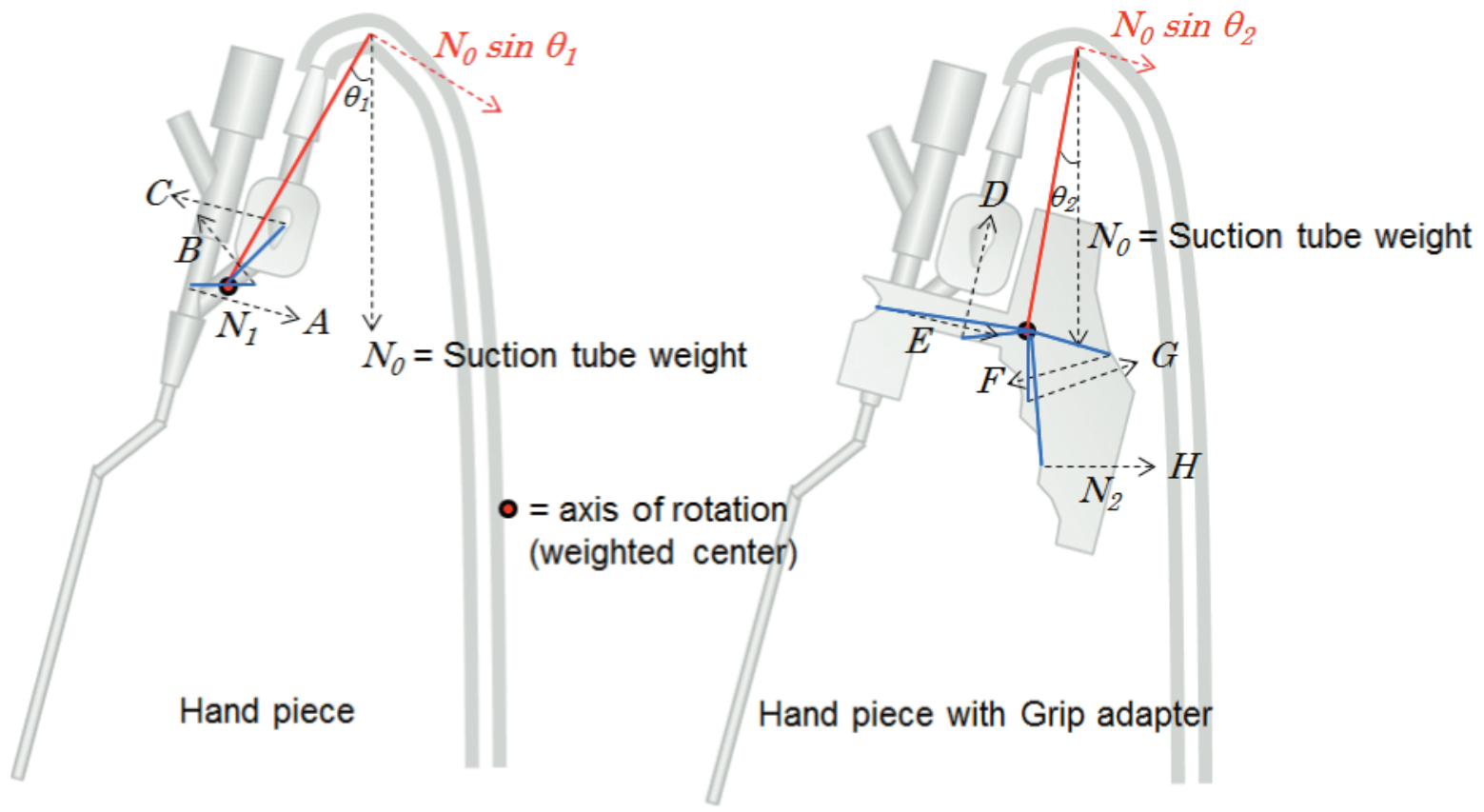

Fig.8 Moment by suction tube weight and by holding hand and finger. A to $\mathrm{H}$ means force vector, red line and blue line is a moment arm

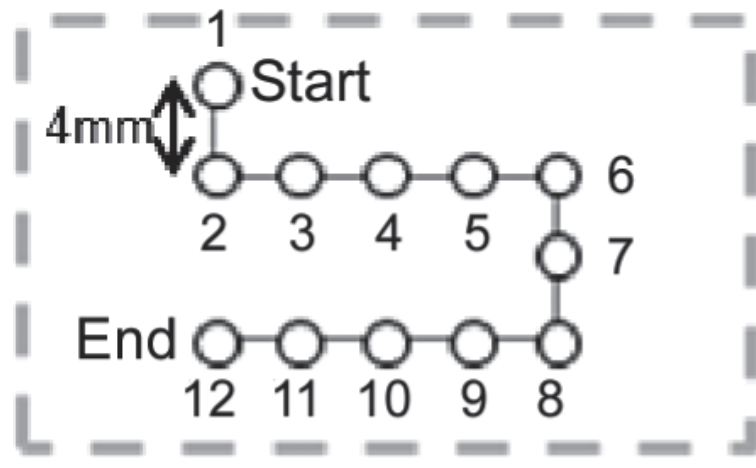

Fig. 9 LILJ target pattern image. Trial subjects shot from No. 1 circle to 12 .

ここで用いた基準パターン画像を Fig.9 に示す。な お実際の実験に用いたパターンには本図中に記した “Start”, “End”, 1〜12の番号, $4 \mathrm{~mm}$ の長さ表記等は 記載せず，丸印と点線のみ印刷した。

前述 2.1.2にて明らかにした術者姿勢（Fig. 4）と 同様の首, 手首, 肘の曲げ角度, 姿勢を再現するよう に，ファントムを設置した机の高さやワーキングス ペースを調整した. 被験者姿勢写真を Fig. 10 に示す.

また LILJ 使用時間の大半が顕微鏡下となる下垂体 手術環境を再現するため, 評価実験被験者はファン トムを直接見るのではなく，ファントム直上に設置 したビデオカメラで撮影した映像を被験者正面に設

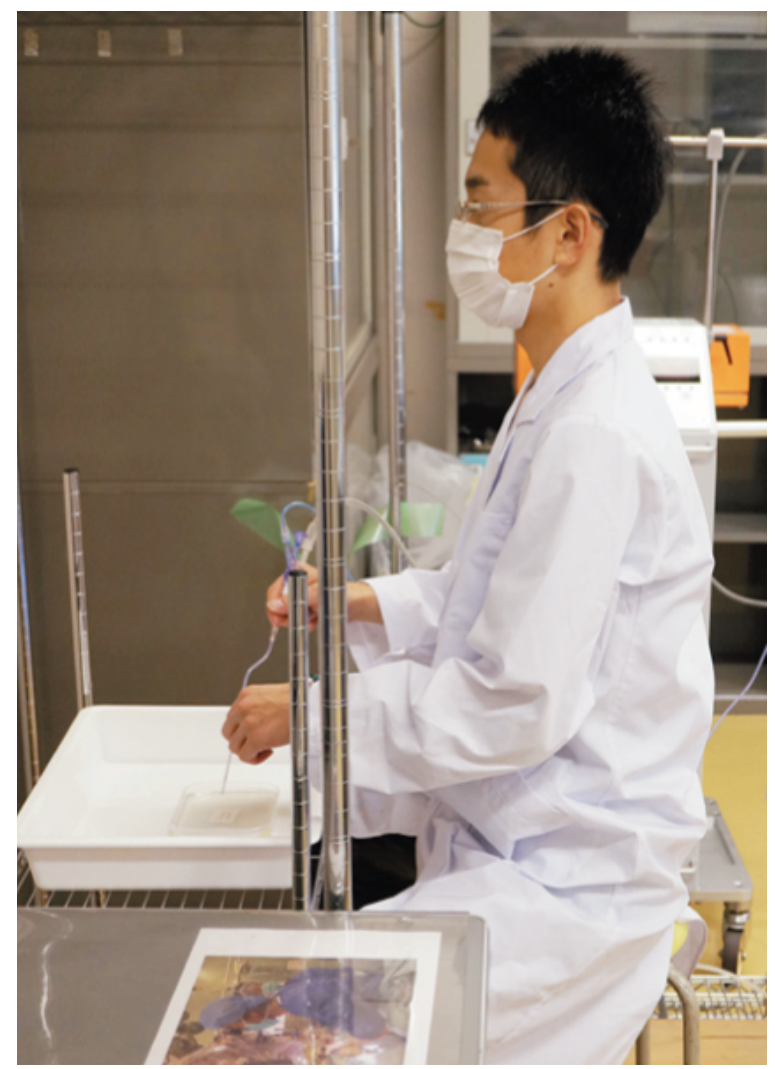

Fig. 10 The posture of trial subject modeled with operator in surgery. 


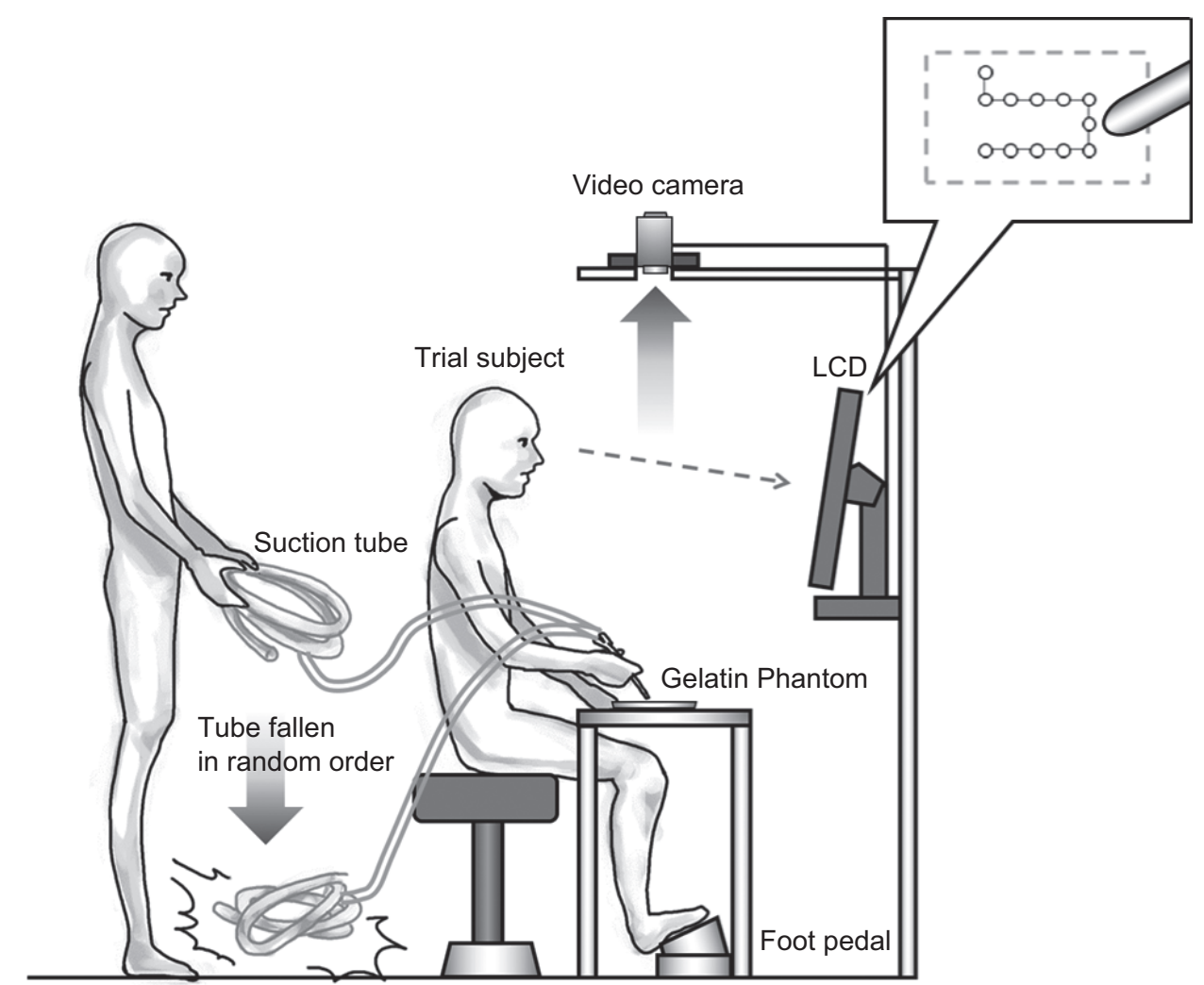

Fig.11 The overview of ergonomic experiments. During shoot operation, suction tube was fallen as a disturbance input. The turbulence distance were recorded video camera.

置したモニタに拡大して出力し，そのモニタを介し て間接的にファントムを見ることとした。

以上の手術環境を模擬した実験環境の模式図を Fig. 11 に示す.

\subsection{2 評価実験プロトコル}

被験者は 22 50 歳の右利きの成人男性で，予備実 験により技術水準の似通った 14 名とした。いずれも 医師ではなく工学系の研究者や学生である.

1 回の評価実験に扔いてジェットを射出している 時間を，前述のように臨床に扔ける最短 LILJ 連続使 用時間と同程度の約 10〜20 秒以内に収めるような実 験プロトコルを設定した.

本実験環境下において行う実験プロトコルを以下 に示す

な脑ジェットメスの出力パラメータはすべて下垂 体手術に扔いて主要に用いられる, $0.7 \sim 0.8 \mathrm{kv}, 3 \mathrm{~Hz}$ とした

1 ）ジェットメスのハンドピースへ給水管, 光ファ イバ, 吸引管ケーブルを接続する。ただし吸引管ケー
ブルのもう一方の端は, ジェットメス本体の吸引バッ グには接続せず, 束ねておく。これをジェットメス操 作する被験者とは別の,ケーブル操作者がこれを持っ ておく.

2 ）ジェットメ久を操作する被験者（以下ジェッ トメ久操作者）は, パ夕ーン画像中の丸印の 1 番から 12 番まで順番に撃つ。

3) 1 つの丸印に対しては連続して 3 発撃ち, 途切 れることなく次の丸印を撃つ。

4) 丸印が 8 番目以降，12 番目までの間で, ケー ブル操作者が手に持った吸引管ケーブルの束 を 1 回だけ地面に落とす。

5 ）ケーブル落下後もジェットメス操作者は 12 番 までジェットを撃つ操作を続ける。

6 ）一人の被験者に対し, ハンドピースのみと, グ リップアダプタを装着したハンドピースで 1 回ずつ行う.

な抢ケーブル操作者は, ケーブル落下の厳密な夕 イミングをジェットメス操作者には伝えない。ただ し，8 番から 12 番の丸印のどこかでケーブル落下す 


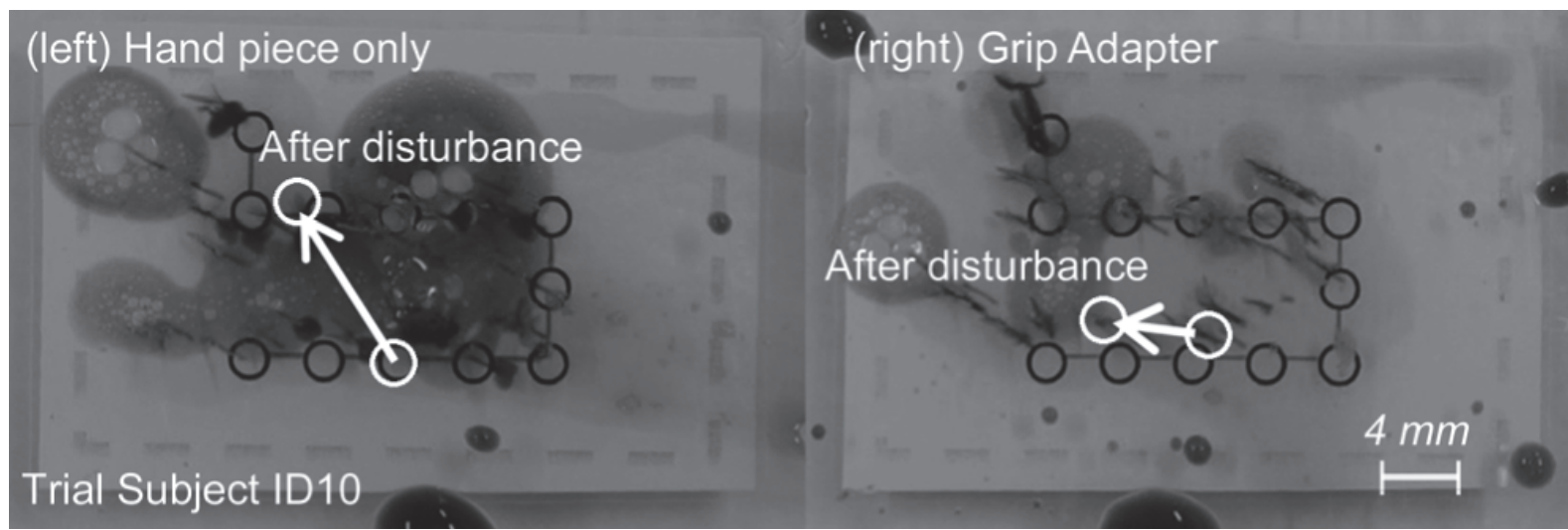

Fig.12 The trial subject ID10's results image of ergonomic experiments. Left image is with original hand piece and right image is with grip adapter. The shot points were stained with ink. The head of LILJ pipe were moved by disturbance input.

ることは事前に操作者に伝えて実験を施行した，落 下する前は, ジェットメスハンドピースとほぼ同じ 高さから落下させた。

学習効果の影響を鑑みるため, 被験者 7 名を『グ リップアダプタ無し $\rightarrow$ 有り』の順. 残り 7 名を, 『グ リップアダプタ有り 無し』の順で実験を行った。

実験後のゼラチンにカラーインクを滴下すること で，ジェット射出された箇所にインクが毛細管現象 で浸透し可視化できる。実験後写真とビデオ映像か ら判断し，吸引管ケーブル落下時のジェット射出位 置と, ケーブル落下の衝撃で丸印パターンとは別の 箇所を誤射した位置の距離を計測し，誤射距離とし た。

\subsection{3 通常使用時評価}

まずLILJ ハンドピースにグリップアダプタを取り 付ける事で通常の使用に影響があるかどうかを調心゙ るため, 評価実験において外乱を入力する前のジェッ 卜射出結果を用いて評価した。ゼラチンファントム に沈めた基準パターン（Fig.9）における番号 2 から 6 までの直線状に繋がる丸印について, 実際に撃った 箇所と直線からのずれの平均を求めた。 その結果, 直 線状の対象をジェットで撃った場合, 基準からのず れの実寸平均はグリップ無しで $1.26 \pm 0.45 \mathrm{~mm}, \quad ク ゙$ リップ有りでは $1.22 \pm 0.22 \mathrm{~mm}$ となり, 両者に有意 な差はみられなかった。

\subsection{4 外乱入力評価実験結果}

被験者 ID $=10$ の評価実験結果のゼラチンファン トムの写真を一例として Fig. 12 に示す.
画像左がグリップアダプタ無し，右がグリップア ダプタを付けた結果である。実験中に撮影したビデ オ映像から計測した, 吸引管落下の外乱入力の前後 のジェット射出位置を白丸で示した。被験者 ID10 は グリップ無しでの誤射範囲は $9.19 \mathrm{~mm}$ だったのが, グリップ有りにすることで $3.24 \mathrm{~mm}$ に短縮した。

順番として先にグリップアダプタ無しで実験を行 い, 次に有りで行った被験者実験（n=7）において， グリップアダプタ無しでの誤射範囲が $17.94 \mathrm{~mm}$ $(\mathrm{SD}=5.73)$, 有りでの誤射範囲が $7.13 \mathrm{~mm}(\mathrm{SD}=$ 1.82)であり,グリップアダプタを付けることで誤射 範囲が 40\%に低減した。これら 2 群の計測值の差が 統計的に有意か確かめるため, 有意水準 5\%で両側検 定の $\mathrm{t}$ 検定を行った結果, $t(6)=4.35, p=0.005$ で あり, 両群の平均值の差は有意であった。

先にグリップアダプタ有りで実験し，次に無しの 順番で実験を行った被験者実験（n=7）においては, グリップ有りでの誤射範囲が $11.09 \mathrm{~mm}(\mathrm{SD}=7.09)$, 無しでの誤射範囲が $21.05 \mathrm{~mm}(\mathrm{SD}=8.97)$ で,グリッ プアダプタを付けることで誤射範囲は $53 \%$ に低減さ れていた．先のプロトコル同様に有意水準 5\%で $\mathrm{t}$ 検 定を行った結果, $t(6)=3.63, p=0.01$ であり, 両群

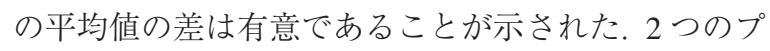
ロトコルでの誤射範囲計測結果の散布図を Fig. 13 に 示す.

同じ被験者のグリップ付け替え前後のデータを矢 印で示した。

$\mathrm{n}=14$ 全ての被験者データを総合すると, グリップ

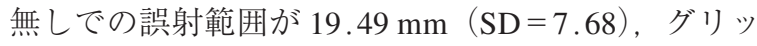
プ有りでは $9.11 \mathrm{~mm}(\mathrm{SD}=5.54)$ となり, グリップ 

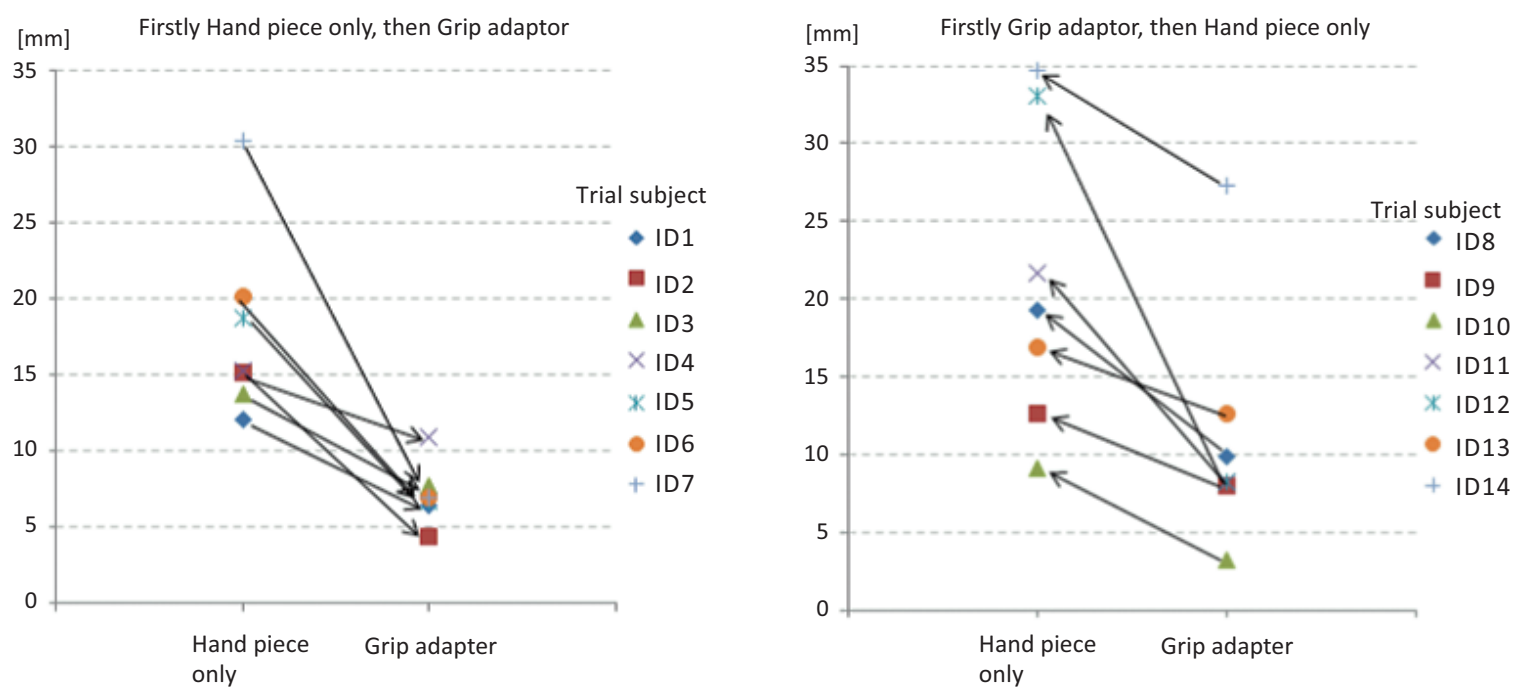

Fig.13 The point diagram which shows moving distance by disturbance input under the condition of hand piece only and with grip adapter both. Left diagram shows that the 7 trial subjects used firstly hand piece only and then with grip adapter. Right shows that the results by another 7 trial subjects who used reverse sequence order.

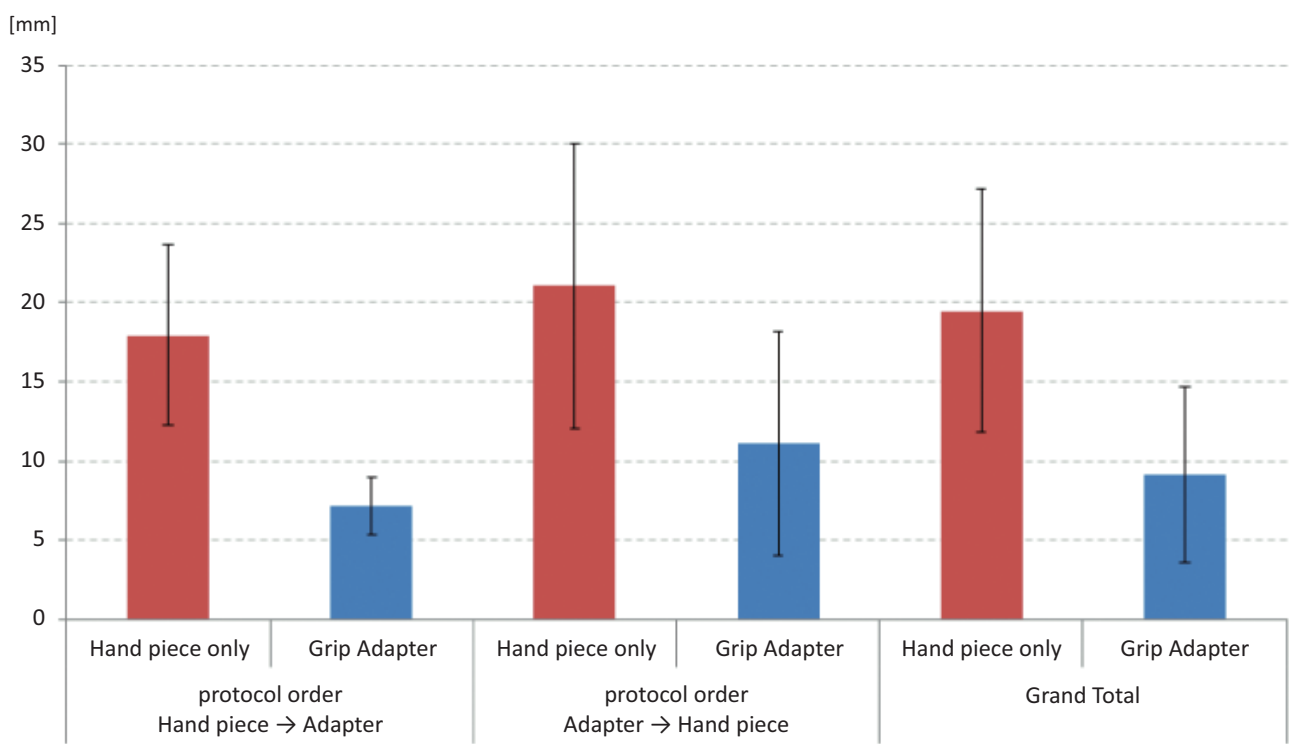

Fig.14 The bar graph which shows moving distance by disturbance input.

アダプタを付けることで誤射範囲を 47\%に低減し た。誤射距離計測結果の平均を棒グラフにまとめた ものを Fig. 14 に示す.

\section{3. 考察}

\subsection{LILJ ハンドピースグリップアダプタの設計}

LILJ ハンドピースに取り付けるグリップアダプタ そのものの工学的評価を行い, 設計仕様として挙げ た，(1）把持の際に手のひら中心に重心位置を持つ, (2) 従来吸引操作に関わらなかった薬指, 小指での確
実な把持，による安定度向上を実現した。

グリップアダプタを取り付けることで $14 \mathrm{~g}$ から 62 $\mathrm{g}$ へと重量が増したが, これは脳神経外科で治療機器 として用いられる超音波吸引器 CUSA エクセルプラ ス $^{\mathrm{TM}}$ (インテグラ社) のハンドピース重量カタログ值 （125 165 g）よりも軽量であり，許容範囲と考えら れる7)。また，通常の使用を想定した環境下での ジェット射出の基準からの誤差範囲が, グリップ無 しで $1.26 \pm 0.45 \mathrm{~mm}, \quad$ グリップ有で $1.22 \pm 0.22 \mathrm{~mm}$ と，両者に差が無く,グリップアダプタを付けたこと 
による通常使用への影響はほぼ無いと考えられる。

\section{2 外乱入力によるハンドピース保持ロバスト 性評価}

もともとヒトは優れた把持能力を持ち, 対象とな る物体の大きさや形に応じて適切な手の形を準備す るプリシェイピング (preshaping) を無意識に行うこ とが知られている ${ }^{8) .99}$ 。一方，手術現場において医師 は清潔野を保全するため常にゴム手袋をした状態で 様々な機器を把持し操作する。そのため急な外乱が 与えられた場合，すぐさま最適な把持位置に手指を 制御できない可能性がある。ささら多施設臨床研究 における下垂体腫瘍摘出における経蝶骨洞手術では 上口唇下粘膜の切開大きさは約 20〜30 mm であり, 内視鏡を併用した場合でも最大約 $30 \mathrm{~mm}$ 径程度の大 きさとされる ${ }^{10)}$. 仮にこの切開範囲を正円に近似し た場合，術野中心にジェットメ久先端が位置してい れば切開壁への距離は最大約 $15 \mathrm{~mm}$ となり, 吸引管 ケーブルの落下のような急な外乱が生じたとしても, 術野端の患者の肉体に衝突して侵襲する可能性を大 幅に低減させたと考えられる。

医療機器の操作性評価を人間工学的に解析した研

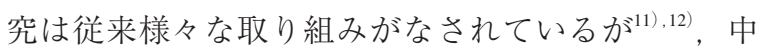
でも歯の切削に打ける姿勢と精密操作の評価を行っ た研究では, 評価実験として表面に数ミリ長の十字 マークを印字した人工歯を直径 $1 \mathrm{~mm}$ の切削器具で なぞるように切削させ，基準線からのズレを計測し て評価指標に用いており ${ }^{13)}$ ，このことからジェット 射出位置と基準線とのズレを評価指標に用いた本研 究の手法も一般的に理解の得られる手法と考えられ る。

\subsection{1 評価手法に関する限界}

一方で，本評価実験にはいくつかの限界が存在す る.

まず評価実験システムとしては，外乱入力として の吸引管落下の衝撃の大きさが厳密には定量化が困 難な事や，脳外科用顕微鏡下での実験では無いため 被験者の絶対的な視野が大きい事が挙げられる。解 決策として, 本研究では吸引管落下前の高さを被験 者がハンドピースを持つ手の高さとして揃えて実験 を行った。また座った状態の被験者の姿勢，腕や手首 の保持姿勢，首の角度（顔の向き）は顕微鏡下手術時 の術者と同じ姿勢になるよう表示装置の高さやファ
ントム位置を調整した.

被験者に関して，被験者が医療従事者ではない点 が脳外科治療機器の評価として十分で無い可能性が ある、ただし，本評価実験ではファントムのパターン 画像やジェット射出メニューは下垂体手術に最適化 されたものではなく，あくまでハンドピースを物理 的に緻密に操作する場合の使用感のみを評価してお り，その範囲での一定の評価は可能と考えらえる.

\subsection{2 グリップアダプタ使用者の感想}

被験者実験被験者 14 名に, グリップアダプタを取 り付けたハンドピースの使用感について感想を聞い た。実際にジェットをゼラチンファントムに撃ちこ んだ実験結果の可視化画像には反映されなかったが, 外乱入力時以外の通常使用においても, グリップア ダプタがあることで安定して操作が可能だったとの 感想が得られた

また，LILJ 多施設臨床研究に参画した脳外科医師 1 名を対象に, 本研究で製作したグリップアダプタを 取り付けたハンドピースの試し撃ちを実施し, 感想 を聞いた。その結果

1) 薬指, 小指による把握によって保持安定度が 向上し，不安定な操作感の払拭による安心感 の向上が見込まれる。

2 ) 通常脳神経外科医師が用いる治療機器の使用 時の指配置とは異なるため, 違和感を強く持 つ医師が出る可能性はある。

との意見が得られた。

このようにユーザー評価を取り込む形での医療機 器の反復設計としては, ロボット鉗子操作部の開発 等でも実施されており ${ }^{14)}$, 今後も多種多様なユーザー の意見を反映させることで, さらなる操作性の向上 が期待できる.

\subsection{3 医療機器の使用感評価に関する海外動向 との比較}

既存の医療機器開発に㧍ける使用感, 安全性評価 の指標としては，アメリカ食品医薬品安全局（FDA） が発表した医療機器設計のガイドラインをまとめた “Do It By Design” ${ }^{15)}$ 内に記述があり，その中で FDA は

医療機器は

・術場環境

・術者の能力 (user capabilities) 
・術者のストレス（stress levels） とデバイスのデザインの相互作用が十分に機能して 初めて安全に使用され得ると定義している。その安 全使用のための設計指針としては，(1）幅広いユー ザーが，（2）ストレス無く使用可能で，（3）誤作動・ 誤用の発生確率がきわめて低く，(4) 加えてトレーニ ングの必要が無いことが望ましいとされている。こ の事項は本研究での研究目的とも十分合致するもの である。

加えて, 術者が保持するような医療機器の指針と しては, 䛊用, 䛊作動を招きやすい要因として“parts that are hard to locate visually or by touch”とあるが，本 研究で製作したグリップアダプタはジェットメスア プリケータと組み合わせることで，中指，小指の保持 する部分，吸引をコントロールする親指の位置は明 確であり，この設計指針と矛盾しないと考えられる。

\section{4. 結論}

LILJ を用いた脳神経外科下垂体腫瘍摘出手術の多 施設臨床研究において, 術者から改善を指摘された ハンドピースの使用感向上について, 外装型のグリッ プアダプタを製作し，アダプタそのものの物理学的 評価，および使用感評価アルゴリズムを作成し人間 工学実験による評価を行った。

重心を回転軸に見立てた吸引管ケーブルの重量に よる回転モーメントを計測し，そのモーメントを打 ち消すように手指が制御するモーメントを計算し, 各指がハンドピースに掛ける力を仮想的に算出した その結果，グリップアダプタを装着することで各指 がかける力を $1.40 \times 10^{-3} \mathrm{~N}$ から $0.4 \times 10^{-3} \mathrm{~N}$ へ $29 \%$ 低減できることが示唆された。

現在, 改良を前提とした医療機器の使用感に関す る評価手法が未だ確立していないこと，本 LILJ 装置 が未承認医療機器であることから, 既存の評価手法 ではハンドピース使用感の評価が十分に実施できな い, そのため本研究では LILJ ハンドピースの操作に 最適化した使用感評価アルゴリズムを新たに作成し， 評価を行った，開発したグリップアダプタ付きハン ドピースの使用感評価プロトコルとして, 外乱入力 時の誤射範囲を定量評価する手法を考案し, 被験者 14 名に対して評価実験を行った。従来のハンドピー スに対してグリップアダプタを装着することで予期 せ㚫引管ケーブルの落下による誤射範囲を $19.5 \pm$ $7.7 \mathrm{~mm}$ から $9.1 \pm 5.5 \mathrm{~mm}$ と $47 \%$ に低隇することを
示した.

今後 LILJ とは別の新たな治療機器を新たに開発す る場合においても, 本研究の評価実験で用いた，間接 的視野, 基準パターンによる規定操作, 外乱による操 作誤動作範囲の計測, といった指標要素は, 機器の使 用感評価指標として活用可能と考えられる.

\section{文献}

1) Hirano $T$, Nakagawa $A$, Uenohara $H$, et al. Pulsed liquid jet dissector using holmium: YAG laser-a novel neurosurgical device for brain incision without impairing vessels. Acta Neurochir（Wien）2003:145:401-406

2) Nakagawa A, Hirano T, Jokura H, et al. Pulsed holmium yttriumaluminum-garnet laser-induced liquid jet as a novel dissection device in neuroendoscopic surgery. J Neurosurg 2004;101:145150

3) Ohki T, Nakagawa A, Hirano T, et al. Experimental application of pulsed Ho: YAG laser-induced liquid jet as a novel rigid neuroendoscopic dissection device. Lasers Surg Med 2004;34: 227-234.

4) Ogawa Y, Nakagawa A, Takayama K, et al. Pulsed laser-induced liquid jet for skull base tumor removal with vascular preservation through the transsphenoidal approach: a clinical investigation. Acta Neurochir（Wien） 2011;153 (4) :823-830.

5) Hirano $T$, Komatsu M, Saeki $T$, et al : Enhancement of fibrinolytics with a laser-induced liquid jet. Lasers Surg Med 2001;29:360-368.

6）杉野宏子, 杉野芳宏, 龍口幹夫. ウォータージェットメス： 原理と医学一の応用. 医科器械 1987;8:23-28.

7) http: //www.integralife.com/products \% 2Fpdfs \% 2Fns5198_ cusa_hp_sellsheet.pdf

8) Flash T, Hogan N. The coordination of arm movements: an experimentally confirmed mathematical model. J Neurosci 1985;5:1688-1703.

9）中村宜孝, 宮里 勉, 岸野文郎. 把持動作における Preshaping の解析とターゲット予測. 電子情報通信学会論文 誌 1997;J80-A-6:1003-1113.

10）中尾直之, 上松右二, 中井國雄, ほか. 下垂体病変に対す る内視鏡支援手術と拡大経蝶形骨洞アプローチ. 日本内分 泌学会雑誌 2004;80:55-60.

11) Yamauchi Y, Suzuki M, Mochimaru, J, et al. A Training System for Endoscopic Sinus Surgery with Skill Evaluation. International Congress Series 2001;1230:1150.

12）山内康司, 山下樹里, 持丸正明, ほか. 内視鏡下鼻内手術 トレーニングシステムの開発と手術スキル評価指標の検 
討. 日本コンピュータ外科学会誌 2002 .

13）井上正義. 歯科診療時の基本姿勢. 人間工学 2009;45:157-

162.

14）富岡 慶, 神野 誠. 人間工学を応用したロボット鉗子新 型操作部の開発. 東芝レビュー 2005;60:36-39.

15) Sawyer D. Do It By Design: An Introduction to Human Factors in Medical Devices. FDA 1997. 